Research paper

\title{
Spatial and seasonal analysis of antimicrobials and toxicity tests with Daphnia magna, on the sub-basin of Piracicaba river, SP, Brazil
}

\author{
Nádia Hortense Torres ${ }^{\mathrm{a}, *}$, Marilia Moura de Salles Pupo ${ }^{\mathrm{b}, \mathrm{c}}$, Luiz Fernando Romanholo Ferreira ${ }^{\mathrm{b}, \mathrm{c}}$, \\ Lucineide Aparecida Maranho ${ }^{\mathrm{a}}$, Juliana Heloisa Pinê Américo-Pinheiro ${ }^{\mathrm{d}}$, Franz Zirena Vilca ${ }^{\mathrm{e}}$, \\ Luciana Maria de Hollanda $^{\mathrm{b}, \mathrm{c}}$, Valdemar Luiz Tornisielo ${ }^{\mathrm{a}}$ \\ a Ecotoxicology Laboratory, Center for Nuclear Energy in Agriculture, University of Sao Paulo, Av. Centenário, 303, Postal Code: 96, Piracicaba, SP 13416-000, Brazil \\ b Processes Engineering, Tiradentes University (UNIT), Av. Murilo Dantas, 300, Aracaju, SE 49032-490, Brazil \\ ${ }^{\mathrm{c}}$ Institute for Technology and Research, Av. Murilo Dantas, 300 (Prédio do ITP), Aracaju, SE 49032-490, Brazil \\ d UNESP Aquiculture Center, UNESP, Rua Prof. Paulo Donato Castellane, s/n, Jaboticabal, SP 14884-900, Brazil \\ e National University of Toribio Rodriguez de Mendoza de Amazonas, Departament of Civil and Environmental Engineering, Calle Higos Urcos, 342-350-356, \\ Chachapoyas, Amazonas, Peru
}

\section{A R T I C L E I N F O}

\section{Keywords:}

Superficial water

Mass spectrometer

Environmental contamination

Aquatic environment

\begin{abstract}
A B S T R A C T
Antimicrobials are pharmaceuticals considered micropollutants because they are found in wastewaters at low concentrations (ng L ${ }^{-1}$ ), which is the case of Enrofloxacin (ENR), Erythromycin (ERY), Norfloxacin (NOR) and Ciprofloxacin (CIP). These compounds are used to treat respiratory, urinary, sexually transmitted diseases, and skin infections being excreted by the body. Due to their composition they are considered of high risk to flora and fauna. The goal of this work was to determine possible concentration of Enrofloxacin, Erythromycin, Norfloxacin and Ciprofloxacin in water, after methodology validation to analyze and monitor the antimicrobials in superficial water and urban supply. Thus, liquid chromatography coupled with mass spectrometer with electrospray ionization source (LC-ESI-MS/MS) was used. The results obtained showed limit of detection (LOD) varying from 0.1 to $0.8 \mathrm{ng} \mathrm{L}^{-1}$; linearity was obtained in the gap between 10 and $200 \mathrm{ng} \mathrm{L}^{-1}$ for Erythromycin, and 40-200 ng L ${ }^{-1}$ for Ciprofloxacin, Norfloxacin and Enrofloxacin. Regression coefficients $\left(\mathrm{r}^{2}\right)$ were over 0.9 and

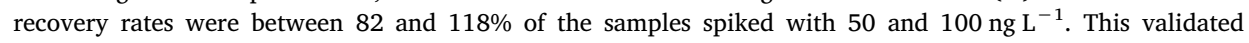
methodology was successfully used to determine antimicrobials level in water samples collected along Piracicaba River and treated water samples of Piracicaba city. From these samples, the antimicrobial mostly found was Norfloxacin in concentrations varying from 8 to $18 \mathrm{ng} \mathrm{L}^{-1}$ in samples collected in dry seasons, whereas Ciprofloxacin, Enrofloxacin and Erythromycin were not found in any of the samples collected. For the $48 \mathrm{~h}$ acute tests with Daphnia magna, Norfloxacin and Erythromycin were considered as "low toxicity", while other compounds did not present any toxicity effect.
\end{abstract}

\section{Introduction}

Lately the occurrence and final disposal of active pharmaceuticals compounds in the aquatic environment has been recognized as one of the most persistent matter in environmental chemistry field [1-3]. Occurrence of antimicrobials in effluents, hospital wastewaters or superficial water motivates the development of resistant bacteria in human and animals [4]. The increase in these so called resistant bacteria reflects in inadequate treatment of these infections requiring the use of more expensive and complex pharmaceuticals for their treatments [5].

Additionally, consideration over contamination with pharmaceuticals have been increasing since these compounds are, also, considered "pseudo-persistent" pollutants due to their continuous insertion in the environment [6]. These even in low concentrations, have the capacity to affect the exposed biota [7], though studies have reported that some of these compounds can be degraded by microbial activity $[8,9]$ or even natural photolysis reactions [10]. However, occasionally the intermediaries generated by these natural routes can be more toxic and persistent in the environment [11].

Among the compounds that affect biota are the antimicrobials from the quinolones group (Ciprofloxacin, Norfloxacin and Enrofloxacin) used in urinary tract infections treatment. These antimicrobials present a wide range of antimicrobial activity, treating gram-negative and

\footnotetext{
* Corresponding author.

E-mail address: nadiahortense@gmail.com (N.H. Torres).
} 
gram-positive aerobic bacteria (enterococcus, streptococcus and staphylococcus) $[12,13]$. As for Erythromycin, it belongs to the macrolide group and due to its posologic ease and higher tolerance that an increase of consumption of this drug has been seen in several countries [14]. As consequence of this growing consumption, prevalence of Streptococcus pneumoniae resistant to macrolides has dramatically increased worldwide in the past 10 years. This progressive resistance to Streptococcus pneumoniae, as well as Streptococcus pyogenes, was positively reported in a wide range of studies [15-19].

Recently, the European Union (EU) emitted 2015/495/EU decision, where 10 macrolide drugs (including Erythromycin) were considered as contaminants with emission restrictions. Further, these compounds were analyzed by Barbosa et al. [20] proving low degradation in conventional wastewater plants, highly interactive presenting synergic effects with high toxicity reinforcing the need to monitoring its emissions. With the consumption of a wide range of antimicrobials, and their simultaneous presence in the environment, interactions with exposed organisms commonly occur [11]. Studies developed by Luo et al. [21] presenting extensive studies of pharmaceuticals incidence point that annual per capita consumption of these compounds can vary from $15 \mathrm{~g}$ to $150 \mathrm{~g}$ in developed countries.

Although many researches show the incidence of these compounds in natural environments, studies to further determine their concentration are still scarce [22,23]. Therefore, in 2009, the World Health Organization (WHO) developed a report in which the need for systematic studies to determine the transport, occurrence and fate of pharmaceuticals in the environment, especially for drinking water was stated. Thus, water sampling and analysis protocols for pharmaceuticals were stablished in order to adequately compare data worldwide [24].

Based on these protocols, [3] analyzed the presence of hormones in Piracicaba river sub-basin finding estriol, estrone, progesterone, 17 $\beta$ estradiol and $17 \alpha$-ethinylestradiol, in concentrations of $90,28,26,137$ and $194 \mathrm{ng} \mathrm{L}^{-1}$, respectively; where estriol was found to be toxic for Daphnia magna in this concentrations.

Therefore, the present study seeks to develop an analytical procedure for detection and quantification of Erythromycin (ERY), Norfloxacin (NOR), Enrofloxacin (ENR) and Ciprofloxacin (CIP), by liquid chromatography coupled to a mass spectrometer with electrospray ionization source (LC-ESI-MS/MS) and evaluate the toxicity of these antimicrobials for Daphnia magna. The validated analytical method was applied to surface water samples collected in six points of the Piracicaba river, and water delivered in households in the city of Piracicaba, in order to determine the concentration of these substances in the water samples.

\section{Experimental}

\subsection{Study area: Piracicaba river sub-basin}

Piracicaba river sub-basin supplies 16 cities, where 3 of them belong to the Corumbataí river sub-basin, still preserved and entirely responsible for the water supply of the city of Piracicaba (SP) [25]. Sampling points were selected due to population density around Piracicaba river (cities of Americana, Santa Bárbara D’Oeste, Piracicaba, Águas de São Pedro and Santa Maria da Serra) which present high contribution of households wastewater [3]. These are points that receive high pollutant load and represent the totality of the analyzed area, sub-basin of Piracicaba river.

Topography features can contribute to water contaminant concentration [26], thus Fig. 1 presents the Topographic map of Piracicaba river sub-basin where the light colors represent lower altitudes and the darker colors the higher altitudes. Still, considering altitudes the area is divided in three categories: area 1, higher altitudes, area 2, peripheral depression, which is lower altitudes; and area 3 , where the area terrain is irregular near the basaltic fields. The area where the samples were collected is of low altitude easing the contributions of Piracicaba river pollutants.
Fig. 2 shows the drainage network of Piracicaba river sub-basin, where it is possible to observe that samples were collected in the area of lower pollutants contributions since the dilution factor is directly proportional to the water flux. According to the Comitê das Bacias Hidrográficas - PCJ (Piracicaba, Capivari e Jundiaî) (2013), the main use of the Piracicaba river formation, in the city of Americana, where the rivers Capivari and Jundiai meet, is as urban area. As for downstream of Piracicaba river, the main use of the resource is for agriculture, seen in sugarcane plantations. Piracicaba river flows at $8.16 \mathrm{~m}^{3} \mathrm{~s}^{-1}$, presenting a $5.24 \mathrm{~m}^{3} \mathrm{~s}^{-1}$ captation and effluent discharge of $5.24 \mathrm{~m}^{3} \mathrm{~s}^{-1}$ [27], which means that the pollutant discharge in this basin is very high, which enables detection of several compounds from the environmental sample collection.

\subsection{Reagents and standards}

All antimicrobial standards that were reagent grade ( $>90 \%$ purity). ENR, CIP and NOR were Fluka Analytical and ERY was purchased from Dr. Ehrenstorfer. Solution were prepared initially with $100 \mathrm{mg} \mathrm{L}^{-1}$ concentration.

\subsection{Water sampling}

Superficial water samples were collected in 6 different points along Piracicaba river and one point of treated water samples were collected in Piracicaba city households (Fig. 3 and Table 1). Sampling and preservation methodology of the water was based on Standard Methods for the Examination of Water and Wastewater [28]. Decontaminated amber jars (soaked in water and soap inside the jars, cleaned with distillated and flowing water, finally rinsed in solution with dimethyldichlorosilane and toluene), were used for sample collection. The water samples, after collection, were then filtrated with a glass fiber filter of $0.47 \mu \mathrm{m}$ (Mackerey - Nagel).

Antimicrobials were extracted from water samples using solid phase extraction (SPE) cartrigeds $(500 \mathrm{mg}, 6 \mathrm{~mL}$, Waters Milford, EUA) coupled to a vacuum chamber (Visiprep $\mathrm{DL}^{\mathrm{TM}}$, Supelco), following previously reported methodology $[29,30]$. The cartridges were conditioned in $4 \mathrm{~mL}$ acetonitrile and $4 \mathrm{~mL}$ of ultrapure water, with $2 \mathrm{~mL} \mathrm{~min}^{-1}$ flow. Afterwards, $200 \mathrm{~mL}$ of water samples were inserted in the cartridge with $2 \mathrm{~mL} \mathrm{~min}^{-1}$ flow. After pre-concentration of the samples, the cartridges were washed wit $4 \mathrm{~mL}$ of ultrapure water, and were dried in a nitrogen gas environment during $20 \mathrm{~min}$. Finally, analytes were eluted with $8 \mathrm{~mL}$ of acetonitrile at $0.5 \mathrm{~mL} \mathrm{~min}^{-1}$. Extract was evaporated completely with nitrogen gas air flow and reconstituted with $4 \mathrm{~mL}$ of acetonitrile: water solution (50:50, v/v).

$\mathrm{pH}$ was not adjusted since the polymeric adsorbent Oasis HLB, when compared to other cartridges is much more efficient, producing elevated recovery rates for all target-compounds. This adsorbent can extract acid, neutral and basic analytes in a wide range of $\mathrm{pH}$, even neutral $\mathrm{pH}$. Therefore, this adsorbent can be used for analyte extraction even with no $\mathrm{pH}$ adjustment [31].

\subsection{High performance liquid chromatography - electrospray ionization - mass spectrometry (HPLC-ESI-MS)}

Chromatographic separation was based in methodology described by [3], applying a High Performance Liquid Chromatograph coupled with a Mass Spectrometer, Agilent Zorbax Eclipse Plus C18 column $(3.0 \times 100 \mathrm{~mm}$, particle size $3.5 \mu \mathrm{m}$; Agilent Technologies), and optimized conditions of acidified ultrapure water using $0.1 \%$ of formic acid with $5 \mathrm{mM}$ of ammonium formate (ratio of 72:28), flow speed of $0.4 \mathrm{~mL} \mathrm{~min}^{-1}$, isocratic mode, injection volume of $10 \mu \mathrm{L}$ and chromatographic scanning time of 6 min.

Mass spectroscopy analysis were carried out using the 6430 triple quadrupole liquid chromatography/mass spectroscopy (LC/MS) system (Agilent Technologies). The Electrospray Ionization (ESI) source was 


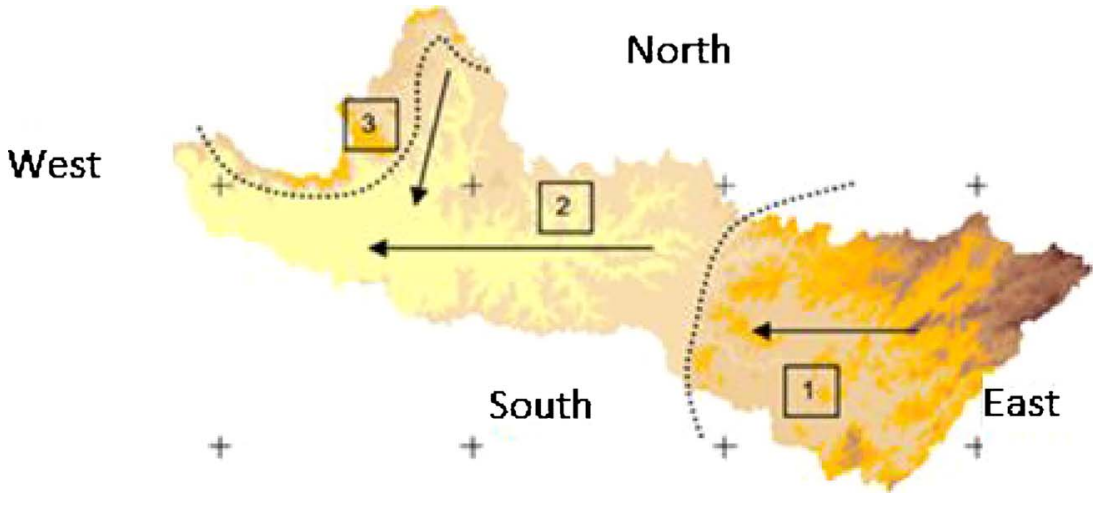

Fig. 1. Topographic map of Piracicaba river sub-basin, extracted from PiraCena (1996).

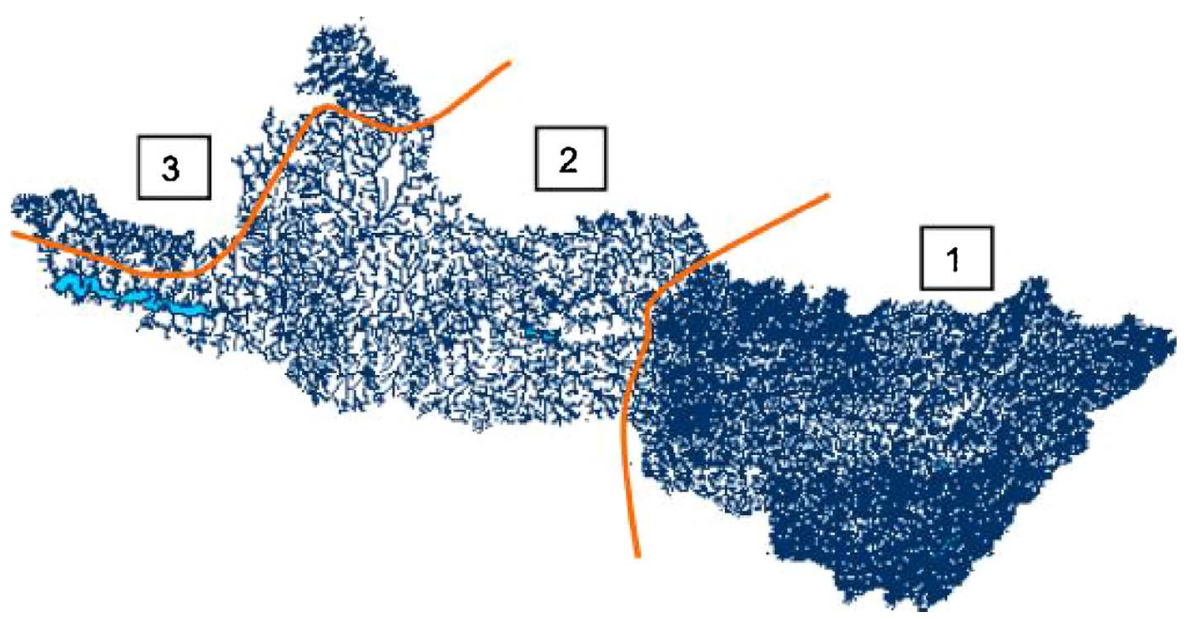

Fig. 2. Draining system of Piracicaba river sub-basin, extracted from PiraCena (1996).

operated in positive ionization mode and its parameters were: drying gas flow of $10 \mathrm{~L} \mathrm{~min}^{-1}$; drying temperature $300{ }^{\circ} \mathrm{C}$, nebulization gas pressure of $40 \mathrm{psi}$ and capillary voltage of $-4000 \mathrm{~V}$. Nitrogen was used as drying gas. Triple quadrupole was used in the multiple reaction monitoring (MRM) to identify and quantify the target compounds. All data were obtained and processed using Agilent Mass Hunter software. In order to reach optimization conditions, individual standard solutions of each compound in a concentration of $20 \mathrm{mg} \mathrm{L}^{-1}$ were injected.

\subsection{Daphnia magna growth}

D. magna cultivation was carried out in a basic growth medium (M4) composed of distillated water with $\mathrm{pH}=7.0$. The organisms were cultivated in glass recipient (crystallizers) of 2 and 3L. Following methodology proposed by Torres et al. [3] growth medium was renewed twice a week considering that at the begging of each week assays with 5 weeks of age were discarded and replaced by neonates collected on the same day. For the remaining days in the week, the aquariums were cleaned and the animals fed.

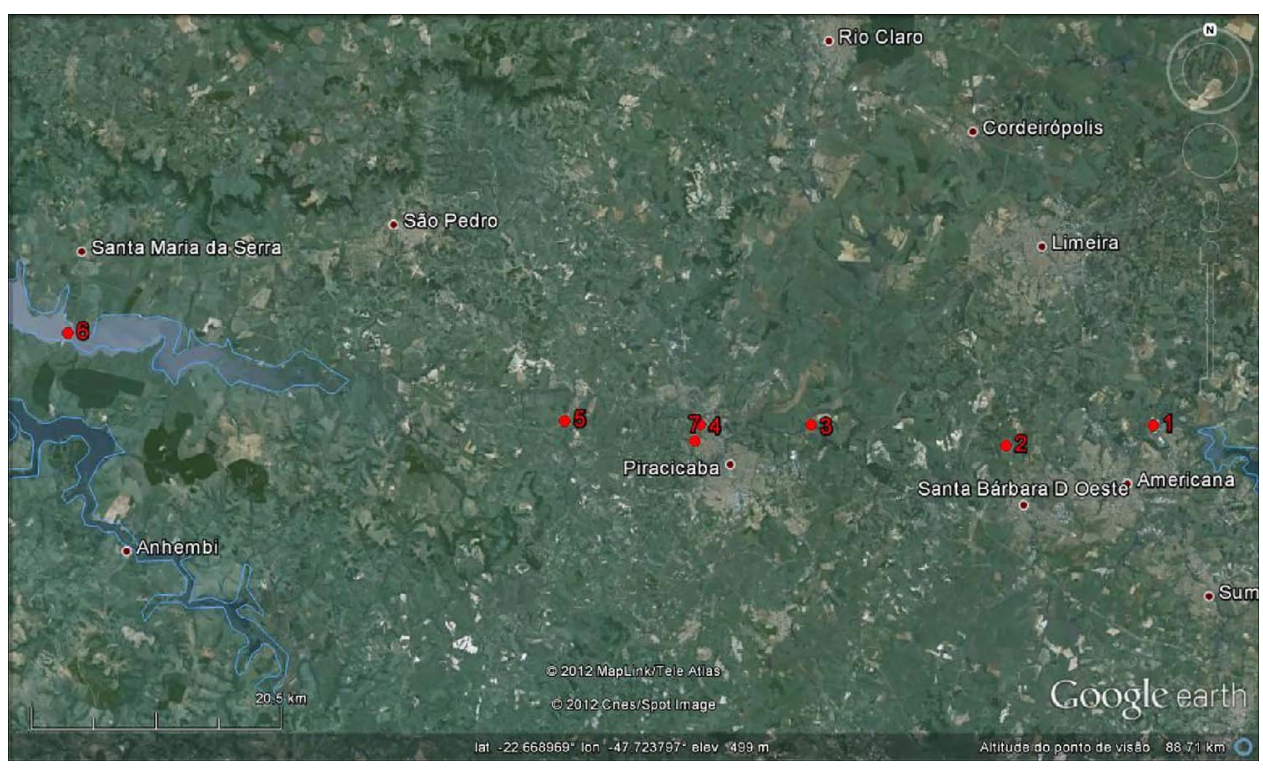

Fig. 3. Satellite image of the area supplied by Piracicaba river, in the state of Sao Paulo, highlighting data sampling points along the river. 
Table 1

Sampling points and their coordinates.

\begin{tabular}{lll}
\hline Site & Type & Coordinates \\
\hline Anhanguera Highway in Americana & River & $22^{\circ} 41.260^{\prime} \mathrm{S}$, \\
city (P1) & & $47^{\circ} 18.678^{\prime} \mathrm{W}$ \\
Exit from Luiz de Queiroz Highway & River & $22^{\circ} 42.651^{\prime} \mathrm{S}$, \\
(P2) & & $47^{\circ} 25.708^{\prime} \mathrm{W}$ \\
Bridge at the entrance of Cooperçúcar & River & $22^{\circ} 41.748^{\prime} \mathrm{S}$, \\
(P3) & & $47^{\circ} 35.003^{\prime} \mathrm{W}$ \\
Caixão bridge in Piracicaba city (P4) & River & $22^{\circ} 41.748^{\prime} \mathrm{S}$, \\
& & $47^{\circ} 40.285^{\prime} \mathrm{W}$ \\
Artemis (P5) & River & $22^{\circ} 41.580^{\prime} \mathrm{S}$, \\
Bridge dam from Santa Maria da Serra & River & $47^{\circ} 46.737^{\prime} \mathrm{W}$ \\
(P6) & & $22^{\circ} 37.666^{\prime} \mathrm{S}$, \\
Treated water from a residence in & Treated water & $28^{\circ} 42^{\circ} 27^{\prime \prime} \mathrm{S}, 47^{\circ} 40^{\prime} 27^{\prime \prime} \mathrm{W}$ \\
Piracicaba city (P7) & & \\
\hline
\end{tabular}

Feeding was carried out using a Raphidocelis subcapitata algae suspension of around $5 \times 10^{6}$ cells $/ D$. magna/day. Additionally, $0.5 \mathrm{~mL}$ of food composed of equal ratios of fermented fish feed and yeast (Saccharomyces cerevisiae) according to regulations from Companhia Ambiental do Estado de São Paulo [32] were also supplied.

The algae solution of Raphidocelis subcapitata used to feed D. magna was cultivated in a medium prepared as described by OECD [33] and ABNT [34], and the growth medium was composed of autoclaved distilled water reconstituted with nutrients.

Food preparation was composed of $5 \mathrm{~g}$ of commercial ornamental fish feed ( $42 \%$ of raw protein) in $1 \mathrm{~L}$ of distillated water and kept for one week under constant aeration. After this period, the filtrated solution, separated in $100 \mathrm{~mL}$ flasks and kept frozen until use. For daily use, $50 \mathrm{~mL}$ of unfrozen prepared feed mixed with $0.25 \mathrm{~g}$ of instantaneous dry biologic ferment diluted in $50 \mathrm{~mL}$ of distillated water was prepared.

\subsection{Acute toxicity tests with the antimicrobials}

The sensibility assays with the test-organisms were carried out in triplicate with Completely Randomized Design (CRD) with three repetitions for each concentration, in a static system. The tests were kept in darkness, in an acclimatized room at $20 \pm 2{ }^{\circ} \mathrm{C}$, static system, without feed or aeration for $48 \mathrm{~h}$. For the $D$. magna test a 5 neonate/ concentration ratio was used. The sensibility control was carried out monthly using sodium chloride $(\mathrm{NaCl})$ as reference for the crustaceous according to the ABNT 12713:2009 protocol, in concentrations of 4.0; 4.5; 5.0; 5.5; 6.0 and $6.5 \mathrm{mg} \mathrm{L}^{-1}$ and a control sample, carried out in triplicate, with 5 neonates/concentration.

For the acute toxicity tests, neonates were exposed to concentrations of ENR, CIP, NOR, and ERY and a control treatment. Testes were carried out in $10 \mathrm{~mL}$ glass test tubes. Dilutions were obtained by adding known values of a standard solution completing the volume with $9 \mathrm{~mL}$ of culture medium. Concentration used varied from 0 to $160 \mathrm{mg} \mathrm{L}^{-1}$. Then, five neonates organisms ( 6 to $24 \mathrm{~h}$ of life) were added, with $1 \mathrm{~mL}$ of growth medium, completing $10 \mathrm{~mL}$ of the test solution. After $48 \mathrm{~h}$, the number of static (or dead) organisms was counted. The tests in which the mortality of control group was higher than $10 \%$ was discarded. These values were used to classify the acute toxicity of ENR, CIP, NOR and ERY according to the toxicological classes used by Zucker [35] (Table 2).

\section{Results}

\subsection{HPLC-MS separation method optimization for identification and quantification of antimicrobials}

In order to optimize chromatographic separation, different mobile
Table 2

Qualitative description of toxicity to aquatic invertebrates Zucker, [35]).

\begin{tabular}{cl}
\hline $\mathrm{LC}_{50}$ or $\mathrm{EC}_{50}$ & Category description \\
\hline$<0.1 \mathrm{ppm}$ & Very high toxicity \\
$0.1-1 \mathrm{ppm}$ & Highly toxic \\
$>1<10 \mathrm{ppm}$ & Moderately toxicity \\
$>10<100 \mathrm{ppm}$ & Slightly toxicity \\
$>100 \mathrm{ppm}$ & Practically non-toxic \\
\hline
\end{tabular}

phases and additives were tested. For the aqueous phase, mobile phases buffered with formic acid in $5 \mathrm{mM}$ concentrations and ultrapure water with $0.1 \%$ of formic acid (to increase sensibility and chromatographic peak resolution) were evaluated, while methanol and acetonitrile were tested as organic solvent. Only these mobile phases were tested because they are most commonly used in sulfonamide and fluoroquinolone analysis $[36,37,12,38]$.

The use of acid aqueous mobile phases is very common for the analysis of antimicrobials, enhancing the ionization efficiency. Combination of aqueous and organic mobile phases were tested in the isocratic mode with $28 \%$ of organic solvent and $72 \%$ of ultrapure water, $6 \mathrm{~min}$ of chromatographic scanning and $0.4 \mathrm{~mL} \mathrm{~min}^{-1}$ flow. This combination was tested using different HPLC columns: (i) C18 Kromasil column (250 mm $\times 4.6 \mathrm{~mm}$ ID, $5 \mu \mathrm{m}$ particle size and (ii) a C18 Zorbax Eclipse Plus column $(100 \mathrm{~mm} \times 3.0 \mathrm{~mm}$ ID, $3.5 \mu \mathrm{m}$ particle size $)$. These columns were tested because columns with C18 stationary phase present better outcomes for the separation of highly polar compounds, such as pharmaceuticals [39]. Combination of the C18 bond and retention time of polar compounds, enhances the performance of the column, service lifetime, stability and peak resolution. A $100 \mathrm{~mm}$ length column was used $(100 \mathrm{~mm} \times 3.0 \mathrm{~mm})$ since the main goal of this work was rapid separation, keeping a good resolution.

Among the combinations cited, the use of the Zorbax Eclipse plus, with acetonitrile as organic phase and ultrapure water both containing $0.1 \%$ of formic acid, were the conditions presenting best resolution, peak format and outcomes, with the chromatographic separation being carried out at $0.4 \mathrm{~mL} \mathrm{~min}^{-1}$ flow to increase separation speed. Temperature was kept at $35^{\circ} \mathrm{C}$. For quantification, two transitions were monitored for each antimicrobial and the optimized conditions are described in Table 3.

\subsection{Validation method}

The method performance was evaluated by the linearity estimation, extraction recovery, sensibility (through detection limit calculation and instrumental quantifications), reproducibility, repeatability and matrix effect. The quantification was based on linear regression calibration curves, from which well fitted curves were obtained $\left(\mathrm{r}^{2}>0.9\right)$ for concentrations determined between 10 and $200 \mathrm{ng} \mathrm{L}^{-1}$ (ERY) and 40 to $200 \mathrm{ng} \mathrm{L}^{-1}$ (CIP, ENR and NOR) (Table 4). Calibration standards were measured at the beginning of each sequence at every 20 to 25 samples, in order to check signal stability.

The Limit of Detection (LOD) and Limit of Quantification (LOQ) were calculated based in parameters of the analytical standard calibration curves [40]. LOD varied from 0.10 to $0.80 \mathrm{ng} \mathrm{L}^{-1}$ and LOQ varied from 8 to $40 \mathrm{ng} \mathrm{L}^{-1}$ (Table 5). These values indicate high sensibility to the mass spectrometer used and its ability to detect antimicrobials at low concentration found in complex environmental samples, such as superficial water [41].

Highest LOD was $0.8 \mathrm{ng} \mathrm{L}^{-1}$ found for NOR, as for CIP $\left(0.4 \mathrm{ng} \mathrm{L}^{-1}\right)$, $\operatorname{ENR}\left(0.4 \mathrm{ng} \mathrm{L}^{-1}\right)$ and ERY $\left(0.10 \mathrm{ng} \mathrm{L}^{-1}\right)$ were lower. For the superficial and treated water, LOQ varied from 8 to $40 \mathrm{ng} \mathrm{L}^{-1}$ (Table 5), which is in agreement to data from [42], in superficial water samples, varying from 1 to $50 \mathrm{ng} \mathrm{L}^{-1}$. With this method, values lower than LOD and LOQ 
Table 3

Target antimicrobials, respective retention time $\left(\mathrm{t}_{\mathrm{r}}\right)$, reaction transition $(\mathrm{m} / \mathrm{z})$, colision and fragmentation energy (both in eV) for positive ionization method.

\begin{tabular}{|c|c|c|c|c|c|}
\hline Antimicrobial & Class & $\mathrm{t}_{\mathrm{r}}(\min )$ & Reaction transition (Precursor ion/product ion) $(\mathrm{m} / \mathrm{z}$ ) & Colision energy (eV) & Fragmentation Energy $(\mathrm{eV})$ \\
\hline \multirow[t]{2}{*}{ ERY } & Macrolide & 2.24 & $734.5 / 558$ & 15 & 125 \\
\hline & & & $734.5 / 158$ & 25 & 125 \\
\hline \multirow[t]{2}{*}{ CIP } & Fluoroquinolone & 3.30 & $332.1 / 314.1$ & 20 & 165 \\
\hline & & & $332.1 / 231$ & 40 & 165 \\
\hline \multirow[t]{2}{*}{ NOR } & Fluoroquinolone & 3.35 & $320.1 / 302.1$ & 16 & 150 \\
\hline & & & $320.1 / 231$ & 44 & 150 \\
\hline ENR & Fluoroquinolone & 4.79 & $360.3 / 342.2$ & 25 & 125 \\
\hline
\end{tabular}

Table 4

Linear regression values and correlation coefficient $\left(\mathrm{r}^{2}\right)$ for the chromatographic method applied to the antimicrobials.

\begin{tabular}{lll}
\hline Antimicrobial & Calibration curves $\left(\mathrm{ng} \mathrm{L}^{-1}\right)$ & Correlation coefficient $\left(\mathrm{r}^{2}\right)$ \\
\hline ERY & $10 ; 40 ; 60 ; 80 ; 100 ; 200$ & 0.95 \\
CIP & $40 ; 60 ; 80 ; 100 ; 200$ & 0.95 \\
ENR & $40 ; 60 ; 80 ; 100 ; 200$ & 0.94 \\
NOR & $40 ; 60 ; 80 ; 100 ; 200$ & 0.94
\end{tabular}

Table 5

Limit of detection and quantification for each target antimicrobial.

\begin{tabular}{lll}
\hline Antimicrobial & LOD $=3.3 * \mathrm{~s} / \mathrm{S}^{\mathrm{a}}$ & $\mathrm{LOQ}=10 * \mathrm{~s} / \mathrm{S}^{\mathrm{a}}$ \\
\hline ERY & 0.10 & 10 \\
CIP & 0.40 & 40 \\
ENR & 0.40 & 40 \\
NOR & 0.80 & 8
\end{tabular}

${ }^{a}$ Where, $s=$ is the standard deviation estimation of the linear coefficient from the line equation of the analytical curve; $S=$ slope or angular coefficient of the analytical curve [40].

were obtained for all antimicrobials, even using low volume of samples for pre-concentration $(200 \mathrm{~mL})$.

Actually, LOD and LOQ estimated in this study are comparable to those obtained through other analytical methods using lower volumes for SPE [43]. In results obtained by Herrera-Herrera et al. [44], LOD for ENR and CIP were 5.61 and $2.58 \mu \mathrm{L} \mathrm{L}^{-1}$, respectively. As for the data obtained in the present work, the values for the same antimicrobials were much lower, $0.40 \mathrm{ng} \mathrm{L}^{-1}$, and also very close to those obtained using SPE on-line experimental system, reported by [45]. Further, it is worth mentioning that, although some of the target antimicrobials, such as ENR, even being frequently used in veterinary medicine [46], it was also included in the validation of the analysis method for superficial and treated water.

Recovery were determined by spiking superficial and treated water samples, in which the standards of ERY, CIP, ENR and NOR were added, in acetonitrile in the concentrations of 50 and $100 \mathrm{ng} \mathrm{L}^{-1}$. These concentration were selected as representative values, since CIP, for example, can be found in high concentrations in real effluents $\left(\log \mathrm{ng} \mathrm{L}^{-1}\right.$, high $\mu \mathrm{g} \mathrm{L}^{-1}$ ) [14].

Seeking to obtain the analyte recovery, extracts were diluted, evaporated and reconstituted with acetonitrile and ultrapure water, using ratio of acetonitrile/water $(50 / 50 ; \mathrm{v} / \mathrm{v})$. The recoveries obtained for the target antimicrobials varied from 82 to over $100 \%$ in some cases, as was also reported for [42]. Method precision, calculated as Variation Coefficient (VC) was satisfactory, varying from 1.77 to $4.88 \%$. All recovery results, standard deviation and variation coefficient for each target antimicrobials are shown in Table 6.

When environmental samples were analyzed, the antimicrobials signal intensity can be, in some cases, considerably suppressed by residuary water matrix, since matrix effects are very common in ESI - MS analysis [47]. Thus, this is the main disadvantage of the ESI - MS method, due to its high sensibility to other compounds present in the
Table 6

Average recovery values (\%), standard deviation $(s)$ and variation coefficient (VC) for each target antimicrobial testes in spiked level $\left(\mathrm{ng} \mathrm{L}^{-1}\right)$.

\begin{tabular}{llll}
\hline Antimicrobial & $\begin{array}{l}\text { Spike } \\
\left(\mathrm{ng} \mathrm{L}^{-1}\right)\end{array}$ & $\begin{array}{l}\text { Average recovery (\%) and standard } \\
\text { deviation }(s)\end{array}$ & CV (\%) \\
\hline ERY & 50 & $117.82 \pm 3.0$ & 2.61 \\
& 100 & $107.75 \pm 3.2$ & 2.94 \\
& Average & $112.78 \pm 3.1$ & 2.77 \\
CIP & 50 & $89.0 \pm 2.5$ & 2.86 \\
& 100 & $115.93 \pm 3.3$ & 2.82 \\
& Average & $102.46 \pm 2.9$ & 2.84 \\
ENR & 50 & $82.0 \pm 6.0$ & 7.31 \\
& 100 & $112.7 \pm 5.5$ & 4.88 \\
& Average & $97.35 \pm 5.7$ & 6.09 \\
NOR & 50 & $89.46 \pm 1.9$ & 2.14 \\
& 100 & $118.33 \pm 2.5$ & 2.08 \\
& Average & $103.89 \pm 2.2$ & 2.11 \\
\hline
\end{tabular}

analyzed matrix, and as result, the signal suppression can lead to analysis bias. Reduction in method sensibility can be caused by several reasons: (i) antimicrobials can be absorbed by organic matter present in the samples, leading to the conclusion that method preparation was not efficient when considering antimicrobials concentration; (ii) contaminants can interfere with the analyte peak elevating the baseline of the chromatogram $[39,48,49]$.

Therefore, the Matrix Effect (ME) was analyzed for superficial water matrix to evaluate how much the target-compounds were sensitive to the signal suppression or interference addition. The method used to analyze the ME is the spiking after extraction [50]. The target antimicrobials presented ME shown in Table 7 for each of the sampling points. The samples collected in 7 points, for the 4 antimicrobials validated presented ME with values lower than $100 \%$, indicating analytical signal suppression (Table 7).

\subsection{Antimicrobials analysis in water samples}

Fluoroquinolones have different behavior than macrolides since they are very susceptible to photodegradation in natural environments [51], besides having strong tendency to adsorb in particulate matter present in suspension in superficial water [52]. Therefore, low concentration in superficial water samples are expected [53].

Table 7

Values obtained for samples with matrix effect of each antimicrobial in each sampling point.

\begin{tabular}{llllllll}
\hline \multicolumn{7}{c}{ Sampling point (P) and ME percentage } \\
\cline { 2 - 7 } Antimicrobial & $\begin{array}{l}\text { P1 (\% } \\
\text { EM) }\end{array}$ & $\begin{array}{l}\text { P2 }(\% \\
\text { EM) }\end{array}$ & $\begin{array}{l}\text { P3 }(\% \\
\text { EM) }\end{array}$ & $\begin{array}{l}\text { P4 (\% } \\
\text { EM })\end{array}$ & $\begin{array}{l}\text { P5 }(\% \\
\text { EM })\end{array}$ & $\begin{array}{l}\text { P6 (\% } \\
\text { EM })\end{array}$ & $\begin{array}{l}\text { P7 (\% } \\
\text { EM) }\end{array}$ \\
\hline ERY & 78 & 88 & 87 & 83 & 87 & 90 & 90 \\
CIP & 88 & 83 & 85 & 82 & 90 & 88 & 94 \\
ENR & 80 & 85 & 83 & 81 & 89 & 90 & 91 \\
NOR & 90 & 91 & 89 & 90 & 92 & 90 & 95 \\
\hline
\end{tabular}


Table 8

Average concentration and standard deviation $(s)$ of NOR in each sampling point (ng L ${ }^{-1}$ ).

\begin{tabular}{ll}
\hline Sampling Point & Average concentration and standard deviation of NOR $\left(\mathrm{ng} \mathrm{L}^{-1}\right)$ \\
\hline P1 & $11.85 \pm 2.8$ \\
P2 & $11.7 \pm 2.7$ \\
P3 & $12.11 \pm 3.2$ \\
P4 & $11.66 \pm 2.6$ \\
P5 & $11.46 \pm 1.7$ \\
P6 & $13.28 \pm 5.0$
\end{tabular}

As for CIP, ERY and ENR was not detected in any of the samples. Since ENR has a very similar metabolite to CIP, its antimicrobial activity has been associated partially to the action of this specific metabolite [54]. As proven in this research, the three compounds were not detected in the samples, probably because they were not consumed in the study area and also, according to [55], these molecules are more susceptible to adsorption in solid suspension, therefore not being detected in the water samples.

On the other hand, NOR was found in samples varying from 8 to $26 \mathrm{ng} \mathrm{L}^{-1}$ (Table 8), where higher concentrations of the compounds are found in dry season, indicating a high consumption of the these compound for urinary tract infection.

For the treated water samples, none of the target antimicrobials were found, which could be due to many different factors, such as, short half-life of these compounds; low hydraulic retention time of the water in the water treatment systems, or even disinfection and photodegradation, which can eliminate up to $80 \%$ of the fluoroquinolones before reaching the environment $[56,57]$. When considering removal of macrolides in conventional water treatments, they are less efficient hence being more persistent in the environment [56], having as main source the direct disposal of household effluents in water bodies [55]. ERY, the macrolide compound analyzed in the present study, was not detected in any of the samples analyzed during sampling period.

Along Piracicaba river, on water sampling points P1 to P5, low values of dissolved oxygen were found, which indicates strong contaminant contribution in this area. The values were lower in rainy season and higher in dry season. $\mathrm{pH}$ was found as expected for natural waters, an average 7.0 . Temperature varied from $19^{\circ} \mathrm{C}$ to $25^{\circ} \mathrm{C}$. The lowest conductivity was seen for water in Santa Maria da Serra dam, while higher values were found in points P1 to P5, indicating a higher degree of dissolved ions in the water.

\subsection{Acute toxicity tests of antimicrobials to Daphnia magna}

In the present work, $48 \mathrm{~h}$ acute toxicity tests with Daphnia magna were carried out presenting toxicity values as results of the Lethal Concentration $\left(\mathrm{LC}_{50}\right) 48 \mathrm{~h}$ of 39.41 and $94.58 \mathrm{mg} \mathrm{L}^{-1}$ for NOR and ERY, respectively, which were calculated with $95 \%$ confidence level using Trimmed Spearman-Karber method [58]. The antimicrobials can be classified as "low toxicity" for Daphnia magna, according to methodology used by Zucker [35].

Further, Liu et al. [59] and Pan et al. [60] also carried out acute tests with $D$. magna during $48 \mathrm{~h}$, and they found NOR toxicity of 180 and $175.8 \mathrm{mg} \mathrm{L}^{-1}$, respectively, while the present study found values of $39.41 \mathrm{mg} \mathrm{L}^{-1}$.

Ecotoxicity tests using Daphnia magna CIP and ENR did not present results that could be described and used to calculate $\mathrm{LC}_{50} 48 \mathrm{~h}$. Further tests to propose new analysis parameters are required evidencing the lack of ecotoxicological studies with Daphnia magna test organisms using pharmaceuticals.

This was the first work at sub-basin of Piracicaba river region conducted with assays testing the ecotoxicity of the antimicrobials ERY, CIP, NOR and ENR in Daphnia magna, because there is a lack in these types of assays in this target region of this study.
Chronic toxicity tests for $D$. magna, were impossible to carry out due to the antimicrobial solubility of CIP and ENR, which impeded the assays. According to Constantine and Huggett [61], based on the life cycle of D. magna, chronic studies to establish survival and reproductive endpoints require a $21 \mathrm{~d}$ exposure period, which increases the total financial cost of the assay.

Andreozzi et al. [62] cited a study that the researchers did not find toxicity effect of the pharmaceutical carbamazepine (CBZ) on a test performed with algae Ankistrodesmus braunii and also found that the concentration of CBZ progressively decreased in the algae culture. They observed that, after 60 days of experiment, over $50 \%$ of CBZ had been removed from the medium. The author concluded that $\mathrm{CBZ}$ was taken up by algal cells and entered into biochemical processes, as might have occurred in the assays involving CIP and ENR in the present study.

\section{Conclusions}

A SPE-LC-MS/MS multi-compound method to evaluate pharmaceuticals in water samples was developed and validated in the present work. Recovery data over $82 \%$ were obtained for the target-compounds of this study. Considering the adverse effects caused by pharmaceuticals emission to natural environments, methods to adequately identify and estimate these compounds are of crucial important. However, due to great dispersion and possible natural degradation and adsorption routes, data with the natural water samples failed to point the great incidence estimated of these compounds in natural environment. Further, the present work successfully developed a cheap and reliable analysis method able to identify and properly estimate concentration of these compounds in natural environments.

\section{References}

[1] R.L. Donnachie, A.C. Johnson, J.P. Sumpter, A rational approach to selecting and ranking some pharmaceuticals of concern for the aquatic environment and their relative importance compared with other chemicals, Environ. Toxicol. Chem. 35 (4) (2016) 1021-1027, http://dx.doi.org/10.1002/etc.3165.

[2] J. Rivera-Utrilla, M. Sánchez-Polo, M. Ferro-García, G. Prados-Joya, R. OcampoPérez, Pharmaceuticals as emerging contaminants and their removal from water. A review, Chemosphere 93 (7) (2013) 1268-1287, http://dx.doi.org/10.1016/j. chemosphere.2013.07.059.

[3] N.H. Torres, M.M. Aguiar, L.F.R. Ferreira, J.H.P. Américo, Â.M. Machado, E.B. Cavalcanti, V.L. Tornisielo, Detection of hormones in surface and drinking water in Brazil by LC-ESI-MS/MS and ecotoxicological assessment with Daphnia magna, Environmental Monitoring and Assessment 187 (6) (2015) 1-13, http://dx doi.org/10.1007/s10661-015-4626-z.

[4] P.M. Da Costa, L. Loureiro, A.J.F. Matos, Transfer of multidrug-resistant bacteria between intermingled ecological niches: the interface between humans, animals and the environment, Int. J. Environ. Res. Public Health 10 (1) (2013) 278-294, http://dx.doi.org/10.3390/ijerph10010278.

[5] A.P. Magiorakos, A. Srinivasan, R.B. Carey, Y. Carmeli, M.E. Falagas, C.G. Giske, et al., Multidrug-resistant, extensively drug-resistant and pandrug-resistant bacteria: an international expert proposal for interim standard definitions for acquired resistance, Clin. Microbiol. Infect. 18 (3) (2012) 268-281, http://dx.doi.org/10. 1111/j.1469-0691.2011.03570.x.

[6] Y. Aminot, K. Le Menach, P. Pardon, H. Etcheber, H. Budzinski, Inputs and seasonal removal of pharmaceuticals in the estuarine Garonne River, Mar. Chem. 185 (2016) 3-11, http://dx.doi.org/10.1016/j.marchem.2016.05.010.

[7] B.I. Escher, R. Baumgartner, M. Koller, K. Treyer, J. Lienert, C.S. McArdell, Environmental toxicology and risk assessment of pharmaceuticals from hospital wastewater, Water Res. 45 (1) (2011) 75-92, http://dx.doi.org/10.1016/j.watres. 2010.08.019.

[8] S.A. Hussain, S.O. Prasher, M. Chenier, G. Arya, Removal of nitrate-N by antibiotic exposed bacterial isolates from constructed wetlands, World J. Microbiol Biotechnol. 27 (9) (2011) 2061-2069, http://dx.doi.org/10.1007/s11274-0110668-8.

[9] J. Ramaswamy, S.O. Prasher, R.M. Patel, S.A. Hussain, S.F. Barrington, The effect of composting on the degradation of a veterinary pharmaceutical, Bioresour. Technol. 101 (7) (2010) 2294-2299, http://dx.doi.org/10.1016/j.biortech.2009.10.089.

[10] X.H. Wang, A.Y.C. Lin, Is the phototransformation of pharmaceuticals a natural purification process that decreases ecological and human health risks? Environ. Pollut. 186 (2014) 203-215, http://dx.doi.org/10.1016/j.envpol.2013.12.007.

[11] S.W. Li, A.Y.C. Lin, Increased acute toxicity to fish caused by pharmaceuticals in hospital effluents in a pharmaceutical mixture and after solar irradiation, Chemosphere 139 (2015) 190-196, http://dx.doi.org/10.1016/j.chemosphere. 2015.06.010.

[12] A. Puckowski, K. Mioduszewska, P. Łukaszewicz, M. Borecka, M. Caban, J. Maszkowska, P. Stepnowski, Bioaccumulation and analytics of pharmaceutical residues in the environment: a review, J. Pharm. Biomed. Anal. (2016), http://dx. 
doi.org/10.1016/j.jpba.2016.02.049.

[13] J.M.B. Silva, C.B. Hollenbach, Fluoroquinolonas X Resistência Bacteriana na Medicina Veterinária, Arquivo Instituto Biológico 77 (2) (2010) 363-369.

[14] A.C. Johnson, V. Keller, E. Dumont, J.P. Sumpter, Assessing the concentrations and risks of toxicity from the antibiotics ciprofloxacin, sulfamethoxazole, trimethoprim and erythromycin in European rivers, Sci. Total Environ. 511 (2015) 747-755, http://dx.doi.org/10.1016/j.scitotenv.2014.12.055.

[15] D. Averbuch, C. Hidalgo-Grass, A.E. Moses, D. Engelhard, R. Nir-Paz, Macrolide resistance in mycoplasma pneumoniae, Israel, 2010, Emerg. Infect. Dis. 17 (6) (2011) 1079-1082, http://dx.doi.org/10.3201/eid1706.101558.

[16] M. Bergman, S. Huikko, P. Huovinen, P. Paakkari, H. Seppälä, Macrolide and azithromycin use are linked to increased macrolide resistance in Streptococcus pneumoniae, Antimicrob. Agents Chemother. 50 (11) (2006) 3646-3650, http://dx doi.org/10.1128/AAC.00234-06.

[17] C. Cilloniz, R.K. Albert, A. Liapikou, A. Gabarrus, E. Rangel, S. Bello, et al., The effect of macrolide resistance on the presentation and outcome of patients hospitalized for streptococcus pneumoniae pneumonia, Am. J. Respir. Crit. Care Med. 191 (11) (2015) 1265-1272, http://dx.doi.org/10.1164/rccm.201502-0212OC.

[18] S.G. Jenkins, D.J. Farrell, Increase in pneumococcus macrolide resistance, United States, Emerg. Infect. Dis. 15 (8) (2009) 1260-1264, http://dx.doi.org/10.3201/ eid1508.081187.

[19] D.J. Serisier, Risks of population antimicrobial resistance associated with chronic macrolide use for inflammatory airway diseases, Lancet Respir. Med. (2013), http://dx.doi.org/10.1016/S2213-2600(13)70038-9.

[20] M.O. Barbosa, N.F.F. Moreira, A.R. Ribeiro, M.F.R. Pereira, A.M.T. Silva, Occurrence and removal of organic micropollutants: an overview of the watch list of EU Decision 2015/495, Water Res. 94 (2016) 257-279, http://dx.doi.org/10. 1016/j.watres.2016.02.047.

[21] Y. Luo, W. Guo, H.H. Ngo, L.D. Nghiem, F.I. Hai, J. Zhang, et al., A review on the occurrence of micropollutants in the aquatic environment and their fate and removal during wastewater treatment, Sci. Total Environ. 473-474 (2014) 619-641, http://dx.doi.org/10.1016/j.scitotenv.2013.12.065.

[22] S. Kim, D.S. Aga, Potential ecological and human health impacts of antibiotics and antibiotic-resistant bacteria from wastewater treatment plants, J. Toxicol. Environ. Health B Crit. Rev. 10 (8) (2007) 559-573, http://dx.doi.org/10.1080/ 15287390600975137.

[23] L. Prieto-rodriguez, S. Miralles-cuevas, I. Oller, A. Agüera, G.L. Puma, S. Malato, Treatment of emerging contaminants in wastewater treatment plants (WWTP) effluents by solar photocatalysis using low TiO2 concentrations, J. Hazard. Mater. 211-212 (2012) 131-137, http://dx.doi.org/10.1016/j.jhazmat.2011.09.008.

[24] M.R. Boleda, M.T. Galceran, F. Ventura, Validation and uncertainty estimation of a multiresidue method for pharmaceuticals in surface and treated waters by liquid chromatography-tandem mass spectrometry, J. Chromatogr. A 1286 (2013) 146-158, http://dx.doi.org/10.1016/j.chroma.2013.02.077.

[25] SAAE, Bacias Hidrográficas dos rios Piracicaba, Capivari e Jundiaí vol. 1, SAAE, Indaiatuba, 2004, pp. 1-24.

[26] L. Ye, Q. hua Cai, R. qiu Liu, M. Cao, The influence of topography and land use on water quality of Xiangxi River in three Gorges Reservoir region, Environ. Geol. 5 (2009) 937-942, http://dx.doi.org/10.1007/s00254-008-1573-9.

[27] CBH-PCJ, Atualização Dos Valores Dos Preços Unitários Básicos Das Cobranças PCJ, Agências das Bacias PCJ (2014) 1-200.

[28] APHA, Standard methods for the examination of water and wastewater, Standard Methods 1 (2012) 541.

[29] L. Tong, P. Li, Y. Wang, K. Zhu, Analysis of veterinary antibiotic residues in swine wastewater and environmental water samples using optimized SPE-LC/MS/MS Chemosphere 74 (8) (2009) 1090-1097, http://dx.doi.org/10.1016/j.chemosphere. 2008.10.051.

[30] R. Zhang, J. Tang, J. Li, Q. Zheng, D. Liu, Y. Chen, et al., Antibiotics in the offshore waters of the Bohai Sea and the Yellow Sea in China: occurrence, distribution and ecological risks, Environ. Pollut. 174 (2013) 71-77, http://dx.doi.org/10.1016/j. envpol.2012.11.008rS0269-7491(12)00486-1[pii].

[31] M. Seifrtová, L. Nováková, C. Lino, A. Pena, P. Solich, An overview of analytical methodologies for the determination of antibiotics in environmental waters, Anal. Chim. Acta 649 (2) (2009) 158-179, http://dx.doi.org/10.1016/j.aca.2009.07.031.

[32] CETESB, Métodos de avaliação da toxicidade de poluentes a organismos aquáticos, (1992).

[33] OECD, (2002). Guideline for testing of chemicals. Freshwater Alga and Cyanobacteria, Growth Inhibition Test. Paris. 21 p. (Guideline \#201).

[34] ABNT, Aquatic ecotoxicology - Acute toxicity - Test with Daphnia spp. (Cladocera, Crustacea), (2009).

[35] E. Zucker, Hazard Evaluation Division, Standard Evaluation Procedure: Acute Toxicity Test for Freshwater Fish, USEPA Publication, 1985 540/9-85-0(1).

[36] M.S. Díaz-Cruz, D. Barceló, Determination of antimicrobial residues and metabolites in the aquatic environment by liquid chromatography tandem mass spectrometry, Anal. Bioanal. Chem. (2006), http://dx.doi.org/10.1007/s00216-0060444-Z.

[37] P. Eichhorn, D.S. Aga, Identification of a photooxygenation product of chlortetracycline in hog lagoons using LC/ESI-ion trap-MS and LC/ESI-time-of-flight-MS Anal. Chem. 76 (20) (2004) 6002-6011, http://dx.doi.org/10.1021/ac0494127.

[38] M.S. Yahya, N. Oturan, K. El Kacemi, M. El Karbane, C.T. Aravindakumar, M.A. Oturan, Oxidative degradation study on antimicrobial agent ciprofloxacin by electro-fenton process: kinetics and oxidation products, Chemosphere 117 (1) (2014) 447-454, http://dx.doi.org/10.1016/j.chemosphere.2014.08.016

[39] M. Gros, M. Petrovic, D. Barcelo, Development of a multi-residue analytical methodology based on liquid chromatography-tandem mass spectrometry (LC-MS/MS) for screening and trace level determination of pharmaceuticals in surface and wastewaters, Talanta 70 (4) (2006) 678-690, http://dx.doi.org/10.1016/j.talanta. 2006.05.024.
[40] M. Ribani, C.B.G. Bottoli, C.H. Collins, I. Jardim, L.F.C. Melo, Validation for chromatographic and electrophoretic methods, Quim. Nova 27 (5) (2004) 771-780, http://dx.doi.org/10.1590/S0100-40422004000500017.

[41] F.F. Sodré, I.C. Pescara, C.C. Montagner, W.F. Jardim, Assessing selected estrogens and xenoestrogens in Brazilian surface waters by liquid chromatography-tandem mass spectrometry, Microchem. J. 96 (1) (2010) 92-98, http://dx.doi.org/10. 1016/j.microc.2010.02.012.

[42] M. Gros, M. Petrović, A. Ginebreda, D. Barceló, Removal of pharmaceuticals during wastewater treatment and environmental risk assessment using hazard indexes, Environ. Int. 36 (1) (2010) 15-26, http://dx.doi.org/10.1016/j.envint.2009.09. 002.

[43] J.M. Cha, S. Yang, K.H. Carlson, Rapid analysis of trace levels of antibiotic polyether ionophores in surface water by solid-phase extraction and liquid chromatography with ion trap tandem mass spectrometric detection, J. Chromatogr. A 1065 (2) (2005) 187-198, http://dx.doi.org/10.1016/j.chroma.2004.12.091.

[44] A.V. Herrera-Herrera, J. Hernández-Borges, T.M. Borges-Miquel, M. ángel Rodríguez-Delgado, Dispersive liquid-liquid microextraction combined with ultra-high performance liquid chromatography for the simultaneous determination of 25 sulfonamide and quinolone antibiotics in water samples, J. Pharm. Biomed. Anal. 75 (2013) 130-137, http://dx.doi.org/10.1016/j.jpba.2012.11.026.

[45] Q. Tuc Dinh, F. Alliot, E. Moreau-Guigon, J. Eurin, M. Chevreuil, P. Labadie, Measurement of trace levels of antibiotics in river water using on-line enrichment and triple-quadrupole LC-MS/MS, Talanta 85 (3) (2011) 1238-1245, http://dx.doi. org/10.1016/j.talanta.2011.05.013.

[46] K. Kukanich, B. Kukanich, S. Guess, E. Heinrich, Effect of sucralfate on the relative bioavailability of enrofloxacin and ciprofloxacin in healthy fed dogs, J. Vet. Intern. Med. 30 (1) (2016) 108-115, http://dx.doi.org/10.1111/jvim.13796.

[47] N. Dorival-García, A. Zafra-Gómez, S. Cantarero, A. Navalón, J.L. Vílchez, Simultaneous determination of 13 quinolone antibiotic derivatives in wastewater samples using solid-phase extraction and ultra performance liquid chromatographytandem mass spectrometry, Microchem. J. 106 (2013) 323-333, http://dx.doi.org/ 10.1016/j.microc.2012.09.002.

[48] B. Kasprzyk-Hordern, R.M. Dinsdale, A.J. Guwy, Multi-residue method for the determination of basic/neutral pharmaceuticals and illicit drugs in surface water by solid-phase extraction and ultra performance liquid chromatography-positive electrospray ionisation tandem mass spectrometry, J. Chromatogr. A 1161 (1-2) (2007) 132-145, http://dx.doi.org/10.1016/j.chroma.2007.05.074.

[49] B.J. Vanderford, R.A. Pearson, D.J. Rexing, S.A. Snyder, Analysis of endocrine disruptors, pharmaceuticals, and personal care products in water using liquid chromatography/tandem mass spectrometry, Anal. Chem. 75 (22) (2003) 6265-6274, http://dx.doi.org/10.1021/ac034210g.

[50] B.K. Matuszewski, M.L. Constanzer, C.M. Chavez-Eng, Strategies for the assessment of matrix effect in quantitative bioanalytical methods based on HPLC-MS/MS, Anal Chem. 75 (13) (2003) 3019-3030, http://dx.doi.org/10.1021/ac020361s.

[51] V. Homem, L. Santos, Degradation and removal methods of antibiotics from aqueous matrices - a review, J. Environ. Manage. 92 (10) (2011) 2304-2347, http:// dx.doi.org/10.1016/j.jenvman.2011.05.023.

[52] B. Li, T. Zhang, Biodegradation and adsorption of antibiotics in the activated sludge process, Environ. Sci. Technol. 44 (9) (2010) 3468-3473, http://dx.doi.org/10. 1021/es903490h.

[53] M.A.F. Locatelli, F.F. Sodré, W.F. Jardim, Determination of antibiotics in Brazilian surface waters using liquid chromatography-electrospray tandem mass spectrometry, Arch. Environ. Contam. Toxicol. 60 (3) (2011) 385-393, http://dx.doi.org/ 10.1007/s00244-010-9550-1.

[54] G. Mengozzi, L. Intorre, S. Bertini, G. Soldani, Pharmacokinetics of enrofloxacin and its metabolite ciprofloxacin after intravenous and intramuscular administrations in sheep, Am. J. Vet. Res. 57 (7) (1996) 1040-1043.

[55] R.M.P. Leal, R.F. Figueira, V.L. Tornisielo, J.B. Regitano, Occurrence and sorption of fluoroquinolones in poultry litters and soils from São Paulo State, Brazil, Sci. Total Environ. 432 (2012) 344-349, http://dx.doi.org/10.1016/j.scitotenv.2012. 06.002 .

[56] A. Gulkowska, H.W. Leung, M.K. So, S. Taniyasu, N. Yamashita, L.W.Y. Yeung, et al., Removal of antibiotics from wastewater by sewage treatment facilities in Hong Kong and Shenzhen, China, Water Res. 42 (2008) 395-403, http://dx.doi org/10.1016/j.watres.2007.07.031.

[57] P. Sukul, M. Spiteller, Fluoroquinolone antibiotics in the environment, Rev. Environ. Contam. Toxicol. 191 (2007) 131-162, http://dx.doi.org/10.1007/978-0 387-69163-3_5.

[58] M.A. Hamilton, R.C. Russo, R.V. Thurston, Trimmed Spearman Karber method for estimating median lethal concentrations in toxicity bioassays, Environ. Sci. Technol. (1977), http://dx.doi.org/10.1021/es60130a004.

[59] K. Liu, S. Xu, M. Zhang, Y. Kou, X. Zhou, K. Luo, L. Hu, X. Liu, M. Liu, L. Bai, Estimation of the toxicity of sulfadiazine to Daphnia magna using negligible depletion hollow-fiber liquid-phase microextraction independent of ambient $\mathrm{pH}$, Sci. Rep. 6 (2016) 39798, http://dx.doi.org/10.1038/srep39798.

[60] Y. Pan, S.-w. Yan, R.-z. Li, Y.-w. Hu, X.-x. Chang, Lethal/sublethal responses of Daphnia magna to acute norfloxacin contamination and changes in phytoplanktonzooplankton interactions induced by this antibiotic, Sci. Rep. 7 (2017) 40385, http://dx.doi.org/10.1038/srep40385.

[61] L.A. Constantine, D.B. Huggett, A comparison of the chronic effects of human pharmaceuticals on two cladocerans, Daphnia magna and Ceriodaphnia dubia, Chemosphere 80 (9) (2010) 1069-1074, http://dx.doi.org/10.1016/j.chemosphere. 2010.05.009.

[62] R. Andreozzi, R. Marotta, G. Pinto, A. Pollio, Carbamazepine in water: persistence in the environment ozonation treatment and preliminary assessment on algal toxicity, Water Res. 36 (2002) 2869-2877, http://dx.doi.org/10.1016/S0043354(01)00500-0. 